\title{
EARTHEN ARCHITECTURE - VALORISATION AND UNDERESTIMATION
}

\author{
N. Barbacci ${ }^{1, *}$ \\ ${ }^{1}$ Norma Barbacci Preservation Consultants LLC, Brooklyn, NY 11226, USA - nbarbacci@gmail.com
}

Commission II - WG II/8

KEY WORDS: Earthen architecture, earth construction, sustainability, conservation, preservation, maintenance.

\begin{abstract}
:
Earthen architecture has been used as a construction material in most of the world for millennia. According to the United Nations, approximately one third of the world population and half of the population of developing countries live in buildings constructed of earth. This presentation makes a basic SWOT (Strengths, Weaknesses, Opportunities, Threats) analysis of earthen architecture in an attempt to explain why this material, possessing many positive qualities, is often maligned or underestimated and dismissed as a construction material associated with poverty, especially in the rural areas of Latin America. This paper emphasizes the importance of maintenance and the preservation of the local socio-cultural knowledge system associated with earth construction.
\end{abstract}

\section{EARTHEN ARCHITECTURE IN THE WORLD}

Earth as a building material, due to its abundance and accessibility, has been used successfully from Saudi Arabia to Argentina, and from Timbuktu to Trujillo. The fertile regions that made possible the development of the Neolithic Agricultural Revolution invited human beings to build their settlements from the alluvial soils, rich in sand, silt and clay, mixed with straw from agricultural crops, and gave birth to the first solid and durable building material: sun-dried earth bricks (Guillaud, 2003).

According to United Nations statistics, approximately one third of humanity and half the population of developing countries live in earth buildings. From humble houses in Puno to buildings with ten or more floors in Yemen, earthen architecture has been used to build homes, churches, mosques, palaces, fortresses, pyramids, barns, defensive walls and other types of structures, many of the which have survived for centuries and even millennia.

In Africa, Djenné-Djennó (Mali), one of the oldest villages in Sub-Saharan Africa, was built of adobe around 250 B.C. and inhabited until 900 A.D., and the Great Mosque of Djenné, rebuilt in 1907, is considered the largest earth building in the world. In southern Morocco, the Berbers developed an earth architecture known as "ksar" or castle, which consists of a walled and dense enclosure located on the edge of the arable land, which constitutes "a perfect example of a bioclimatic adaptation model in the architecture" (Cherradi, 2012).

In America, almost all Pre-Columbian cultures used earth in their constructions, especially in Peru, Mexico and the Southwest of the United States, but also in all those regions where hot and dry weather favored the use of this material.

In Peru, the oldest earth structures date back to the Late Archaic or Pre-ceramic period and are found in the Casma Valley, at the archeological sites of Sechin Bajo (3400 B.C.) and Cerro Sechin (2200 B.C.). Another important example is the Huaca Ventarron in Lambayeque (2300-2000 B.C.), where blocks of yapana or dried alluvial mud were used as construction material (Canziani, 2012). One of the most important earthen architecture sites in Peru is the Huaca de la Luna, a Moche site in Trujillo.

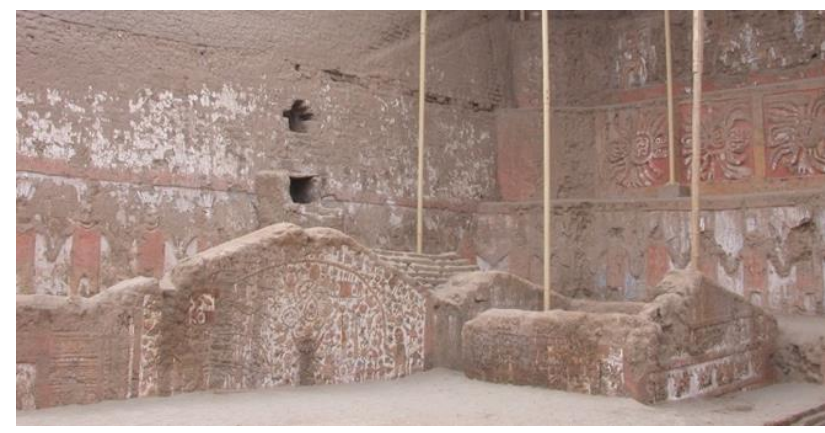

Figure 1. Huaca de la Luna, Trujillo.

In Mexico, the core of the Pyramid of the Sun in Teotihuacán was built of compacted earth, between 300 and 900 A.D., while in the Sierra Nevada of Santa Marta, Colombia, the traditional homes of the indigenous Arhuacos, known as urakais, were made of quincha or wattle and daub (Vargas, Yalmar, 2012).

During the colony, indigenous earth construction systems continued to be used, enriched with new European techniques, so the heritage built between the 16th and 18th centuries is mostly made up of quincha, tapial or rammed earth and adobe brick structures, combined with other materials such as stone and wood. Only from the 19th century, industrialized materials begun to be used in cities and, in the 21 st century, these systems began to displace traditional earth architecture in rural areas (Beltrán, Lina, 2007).

In Asia, one of the first expressions of architecture and the first surviving earth structures are found in Anatolia, Turkey, at the archaeological site of Çatalhuyuk. This Neolithic settlement was built with adobe bricks, between 7500 and 5700 B.C., by a society without hierarchy, of collectors, farmers and shepherds.

\footnotetext{
* Corresponding author
} 
In China, the first structures of the Great Wall were built of earth almost 3000 years ago, and in the Fujian Province there are thousands of rammed earth structures built by the Hakkas between the twelfth and twentieth centuries, known as tolou.

In Japan, the earth construction system known as tsuchikabe or mud wall, consisting of a combination of clay, sand and rice straw, was used from the seventh century on the construction of temples, palaces and houses (Hassel, 2013). The biggest threat to traditional Japanese wood architecture is fire, so the tsuchikabe system became popular in the country as a fireproof system (Mendoza, 2012).

In Europe, the oldest settlements in Europe built of sun-dried bricks were excavated in Thessaly, Greece, and date to approximately 6500 B.C. (Guillaud, 2003).

In Italy, the first Etruscan temples as well as the first monuments of the Roman Republic ( $4^{\text {th }}$ and $3^{\text {rd }}$ centuries B.C.) were constructed of adobe, and Vitruvius, in his $1^{\text {st }}$ century B.C. treatise on architecture, devotes a whole chapter to mud brick construction, while in the Iberian Peninsula, earth construction techniques, introduced by the Romans, were enriched by the Arabs (Garzón, 2007).

During Medieval times, earth was used as fill in wooden constructions. Between the 15th and 19th centuries the rammed earth or terre pisé technique was widely used in France and was especially popularized in Paris by the architect François Cointeraux in the 18th century.

In the Middle East, the regions of the Mediterranean Levant, which today include Lebanon, Syria, Palestine, Israel, Jordan and parts of Iran and Iraq, were the cradle of great ancient cultures which excelled in the art of earthen construction since the 8th millennium B.C. (Guillaud, 2003).

In Iran, the predominant construction system from prehistory to the present is earth, and the first international conference on the Study and Conservation of the Architectural Heritage of Earth (TERRA) took place in Yadz, Iran in 1972. In Yemen, the city of Shibam, known as the "Manhattan of the desert" for its high density of housing, has adobe buildings of 9-10 floors, dating back almost 1600 years ago. The universal value of earthen architecture is evident and deserves the recognition, protection and conservation of the international community. In 2011 approximately $10 \%$ of World Heritage sites were earthen monuments or sites and $25 \%$ of the list of World Heritage in Danger was made up of this type of construction - threatened by floods, earthquakes, industrialization, urbanization, modern construction technologies, disappearance of traditional construction practices, etc. For this reason, UNESCO established the World Heritage Earthen Architecture (WHEAP) program with the objective of improving the conservation and management of earth architecture in the world. The program was active between 2007 and 2017, and developed multiple activities, including: research, international meetings, information exchange, exhibitions, publications, workshops and training courses.

\section{EARTH, AN IGNOBLE MATERIAL?}

The following SWOT (Strengths, Weaknesses, Opportunities and Threats) analysis attempts to explore the reasons why earthen architecture, possessing such good material qualities, such longevity as a construction technique, and such wide geographical distribution, is underestimated in many parts of the world, with a particular focus in Latin America.

\subsection{Strengths}

Raw earth is an ecological material, since it is natural, it does not have to be industrially transformed, it consumes less energy and water than the manufacture of cement and other materials, it does not require transportation since it is everywhere, it is completely recyclable and does not generate waste during its construction or at the end of its useful life. For these qualities Cristian Heinsen of the Altiplano Foundation in Chile, believes that earth should be considered as a material of the future: "Years ago, while restoring the chapel of Chitita, the Aymara master don Mario Cutipa, lectured: 'if you have a concrete or brick wall and you must throw it away, what do you do with the material? It is rubble, but not if it is made of earth - then it is reused.' That is key in the valorization of earth as a technology for the future" (Heinsen, Cristian, personal communication, July, 2019).

It is an economical material and its construction and maintenance techniques are relatively simple and do not require complex knowledge or equipment, therefore it is accessible to almost every nation in the world.

It is resistant since earth architecture, if it is well built and receives continuous maintenance, can endure earthquakes and floods. This feature was developed and exploited during the colonial era, since the debate generated following the destruction by the earthquake of 1609 of the stone and brick vaults of the old Cathedral of Lima. This technical debate between builders concerned with the structural instability of this type of construction during earthquakes resulted in the introduction of new construction systems of greater lightness and flexibility such as vaults made of earth with cane frameworks, the reduction of the height of walls and the increase of their thickness, the introduction of wooden reinforcements and especially, the recommendation to maintain the structures after each earthquake (Hurtado, 2012).

In Peru, an evaluation conducted by the Pontifical Catholic University of Peru (PUCP) of the adobe houses reinforced with cane and asphalt, built in 1973 by the Ministry of Housing, in the Agrarian Cooperative of Cayaltí, Chiclayo, indicated that after 25 years they had resisted the onslaught of El Niño phenomena without major damage, as long as they had received maintenance (Quiun, 2012). Also, the report of the Earthquake Field Investigation Team (EEFIT) of the Institute of Structural Engineers of the United Kingdom, on the results of the earthquake of August 15, 2007 that devastated the central coast of Peru, mentions that the adobe houses that were reinforced by the PUCP or the Japan International Cooperation Agency (JICA) before the disaster in the cities of Guadalupe, Zúñiga and Huangáscar, performed satisfactorily during the earthquake, while all other adobe houses in the surrounding area suffered medium to severe damage or collapsed (Taucer, 2008).

It is healthy since it does not contain toxic elements, it does not pollute the environment in any of its stages and its manipulation is not dangerous.

Earth constructions are comfortable and contribute to the quality of life of their occupants since they have a great thermal inertia: adobe absorbs heat during the day and releases it slowly during the night. Poured earth walls have less thermal conductivity than concrete and brick (Aranda, 2014), and this feature is especially important in the Andes where temperatures can drop to $-22^{\circ} \mathrm{C}$. Earth construction also offers sound insulation and helps control humidity by acting as a sponge. 
It is a versatile material with many construction techniques that range from rammed earth, kneaded earth, tapial, adobe, quincha, etc. Each region has its own systems and they can be adapted to diverse needs. The basic earthen material can be improved with the use of local natural reinforcement products which are often waste, and thus get recycled.

Furthermore, it is a flexible system since it can be built in stages and it can be expanded, reformed and improved during rebuilding.

\subsection{Opportunities}

A significant percentage of the world's population lives in earthen houses and, because of its wide geographical distribution, any improvement in this construction material or technique can have a great worldwide impact.

Building with earth offers the opportunity to express cultural identity through its design, use of local materials and community maintenance activities. In Burkina Faso, the royal complex of Tiébelé, a group of mud constructions painted with geometric motifs, despite the death of the last pe or cacique in 2006, is maintained through a communal effort where the tradition of mud plaster and surface decoration is transmitted from generation to generation. In the Great Mosque of Djenné, the epicenter of the cultural and religious life of Mali and a UNESCO World Heritage site, wooden beams located throughout the exterior are both decorative and structural and also function as scaffolding for the re-plastering of the mosque during the annual festival called Crepissage de la Grand Mosquée or Plastering of the Great Mosque, in which the entire community participates, accompanied by music and singing. Despite the pressure to change certain aspects of the mosque such as replacing the earth construction with concrete, the sand floor with tiles or eliminating music during the maintenance festival, the Djenné community has struggled to maintain this material and intangible cultural heritage intact.

The availability and economic quality of earth as a construction material means that it has great potential to contribute to poverty alleviation and sustainable development. Hassan Fathy, the visionary Egyptian architect recognized as a pioneer in sustainable and participatory architecture was convinced of this and wrote in 1976 the book "Architecture for the Poor: An Experiment in Rural Egypt", where he describes his plan to build the adobe city of New Gourna, Egypt. New Gourna was built between 1945 and 1948 near Luxor, using mud bricks, the native technique that Fathy learned in Nubia, and traditional Egyptian architectural elements such as enclosed courtyards and vaulted ceilings. Fathy worked with the villagers to adapt his designs to their needs and taught them to work with adobe, supervised the construction of the buildings and encouraged the revival of old crafts such as latticework to decorate and ventilate the buildings.

Francis Kéré, an architect based in Berlin, grew up in Gando, a poor rural settlement in Burkina Faso that had no school or medical services. After studying architecture in Europe, Kéré returned to his hometown to build a school together with the community. As a result of his work, Gando revived the ancestral tradition of earth construction and now has schools and homes of good quality and contemporary design, perfectly adapted to the climatic conditions of the region.
In Neuquén, Argentina, the lack of housing and the difficulty of accessing a mortgage loan pushed many to look for construction alternatives that relied on their own labor. Since 2010, the Plottier Agricultural Professional Training Center No. 1 offers a workshop on earthen construction to 40 to 70 people per year. The premise of the workshop is that by building their house with their hands, the owners can reduce construction costs by up to eighty percent less than a traditional construction house (González, Georgina, 2018).

In Puno, Peru, the putucos of adobe and straw are examples of sustainable architecture, accessible to people of limited resources and resistant to floods. In 2014 the Ministry of Culture declared the ancestral knowledge in the construction of putucos as Cultural Heritage of the Nation.

In Mali and Burkina Faso, the Djenné and Kassena communities mentioned before, by preserving their tradition of maintaining their earth structures, are developing an important economic resource, thanks to cultural tourism.

Finally, given the imminent threat of climate change and global warming, earth construction offers a better alternative to concrete, which according to the Chatham House report of the Royal Institute of International Affairs, the concrete industry is responsible annually for $8 \%$ of $\mathrm{CO}_{2}$ emissions in the world. On the other hand, earth constructions have better thermal qualities and therefore require less energy to heat or cool them. How can we explain then that raw earth is not considered a "noble" material such as concrete and brick?

\subsection{Weaknesses}

Because, as with any material, there are some weaknesses. Earth constructions are sensitive to moisture and therefore require protection from rain, water penetration by capillarity and salt crystallization; they are sensitive to wind erosion; and structurally, only work well in compression, require a load distribution (they do not admit punctual loads) and in seismic areas, require special reinforcement, especially at the corners and the connection between walls and foundations. Because of these vulnerabilities, earth is considered a "non-engineered" material (Quiun, 2012).

Earth construction requires continuous maintenance, and deteriorated mud dwellings can offer an ideal habitat for insects that transmit diseases such as the Chagas disease which causes blindness (caused by triatoma dimidiata popularly known as vinchuca), or for parasitic vegetation.

\subsection{Threats}

The most common threats consist of natural disasters such as earthquakes and floods, and those generated by man, such as prejudice, loss of the ancestral knowledge of traditional construction techniques, lack of maintenance and inappropriate interventions.

2.4.1 Earthquakes: In Argentina, the San Juan earthquake of January 1944 destroyed eighty percent of the city, while ninety eight percent of the buildings were built of unreinforced earth.

In Chile, the earthquake of February 27, 2010 damaged a large part of the country's raw earth architecture. "Virtually thirty percent of the buildings declared under the National Monuments Law built in adobe block or some system containing earth was damaged" (Sánchez, 2012). 
In Guatemala, in response to the damage suffered by adobe homes due to earthquakes in 2012, 2014 and 2017, adobe ceased to be the main housing construction material in the country, to be replaced by concrete block. The use of adobe diminished and was listed as a construction risk material, associated with the idea of poverty (Pastor, 2018).

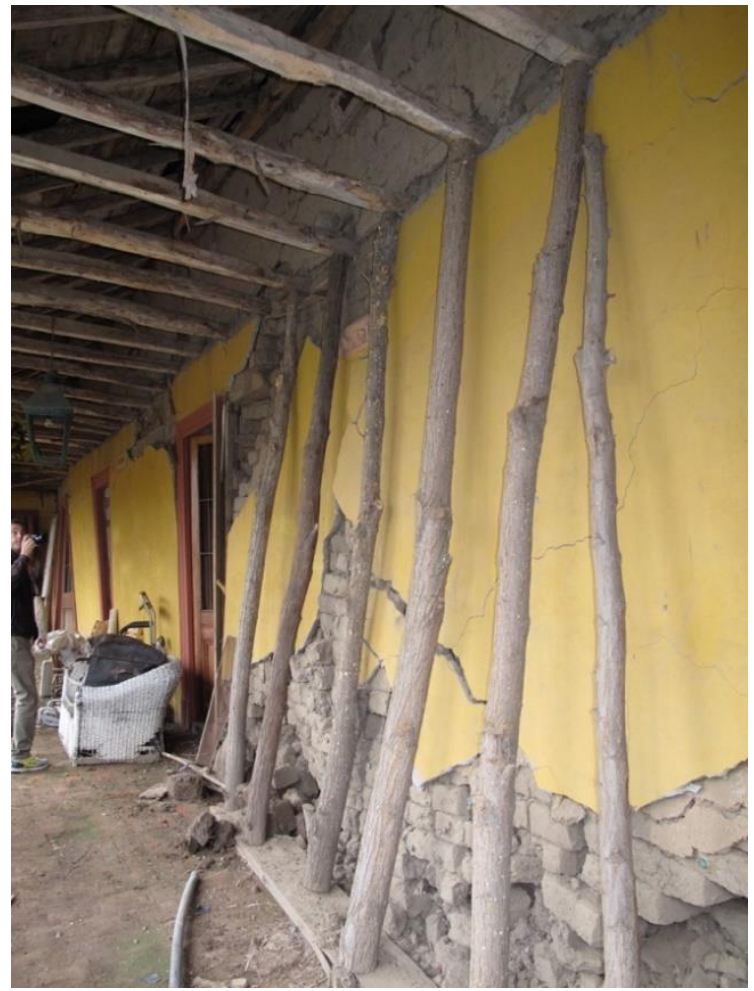

Figure 2. 2010 Chile Earthquake.

In Peru, earthquakes stronger than $6 \mathrm{Mw}$, that occurred throughout the twentieth century until the most recent in 2007, have caused the collapse of thousands of earthen buildings. However, it is worth mentioning some reports that explain the reasons for these collapses.

According to the Earthquake Field Investigation Team (EEFIT) report mentioned above, the earth structures that collapsed during the 2007 earthquake were those of poor construction quality, had walls too thin or too long, had a high percentage of openings such as windows and doors or roofs that were too flexible or heavy (Taucer, 2008). According to the CERESIS / UNESCO report, almost forty eight percent of homes in the Ica Region were made of adobe or tapial, built without any seismic reinforcement. Collapses occurred mainly due to the lack of adhesion between walls and roofs (Giuliani, 2008). It is interesting to note that in this report, they emphasize that the behavior of reinforced concrete buildings during the earthquake was "inferior to that observed in masonry homes built by their owners" (Giuliani, 2008).

In the case of the Church of the Company of Jesus in Pisco, the building had been rebuilt in 1704 after its predecessor was destroyed by an earthquake in 1687, based on the recommendations developed after the collapse of the Lima Cathedral, mentioned before. The church resisted the earthquakes of 1746, 1877 and 1942, without being destroyed, but the cumulative effects of these seismic movements made necessary maintenance and restoration interventions which in 1960 introduced the use of cement to reinforce vaults and walls.
Furthermore, the church's surrounding area was paved with cement and asphalt which, together with the plastic paint used as a finish on the walls, contributed to the concentration of moisture in the earthen structure, resulting in the crystallization of salts and the softening of the adobe. The added lack of maintenance and the attack of xylophages and fungi to the wooden elements, also contributed to the collapse of the church in the 2007 earthquake (Hurtado, 2012).

2.4.2 Floods: In Peru, floods are a recurring phenomenon during the rainy season in the mountains, between the months of November and April. El Niño (ENSO: El Niño Southern Oscillation) contributes to aggravate these disasters, which especially affect the country's earthen architecture.

2.4.3 Prejudice: Much of the world's earthen architecture is considered popular architecture or vernacular because it is of local, native, indigenous, or traditional origin, which automatically gives it a common, folkloric character, a "not being special" that diminishes its value and limits its fair appreciation. According to Graziano Gasparini, "traditional popular architecture is fragile and breaks in the face of the emergence of more convenient new solutions. The traditional is valid until new options arise" (Gasparini, 2009).

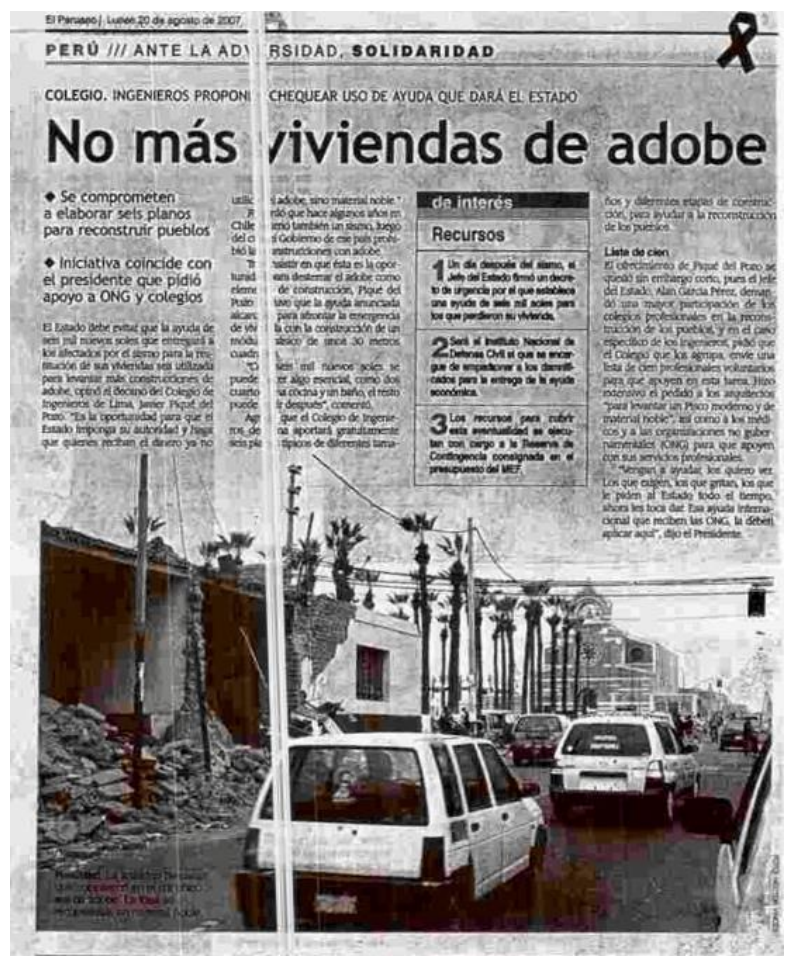

Figure 3. Announcement in El Peruano, August 2007.

The destruction of earthen architecture through earthquakes and floods usually sparks a vociferous public questioning of its capacity to resist natural disasters, and many times, authorities with a short-term vision, issue laws or decrees such as those promulgated in the wake of the earthquakes in Costa Rica (1910), Argentina (1944), or Peru (2007) by which the material became the scapegoat. In my opinion, because it is easier to blame the material, than to explain the conglomerate of bad practices that include failed public construction policies, uncontrolled development, lack of sanitation, lack of investment, poor building supervision, inadequate planning and disaster prevention, inexperienced builders, lack of maintenance, marketing of the cement industry, etc. 
In a study conducted by the Universidad Ricardo Palma in communities of Puno, Peru, its residents indicated that as soon as they receive a higher income, the first thing they do in their homes is to replace the thatched roof with a corrugated metal one because it is considered a more durable material, easier to install and a symbol of modernity, although in practice this material only generates heat losses in the coldest hours of the night. Also, despite recognizing that the adobe-built enclosures are "warmer" than those of stone or metal, these residents indicated that if they had more money, they would replace the adobe with brick, since this is a material used in the city, and therefore associated with a higher economic stratum (Gayoso, Magaly, 2014).

According to the Peruvian historian, Elizabeth Kuon: "Due to sociological problems that are structural in our country, now adobe is ceasing to be the favorite construction material for farmers. The 'noble materials' as they now call concrete, is what is used because it means economic status and therefore social status and a sign of prestige in rural communities, which is why the wonderful small and warm two-story adobe houses, are being replaced by a new landscape of 'modern' materials such as colored polycarbonate, colored glass, tiles, etc." (Kuon, Elizabeth, personal communication, June, 2019).

2.4.4 Loss of Ancestral Knowledge: Another major threat to earth construction is the loss of ancestral knowledge of how to build and maintain this type of buildings.

In the mountainous area of Ladakh, India, Buddhist communities built their earth cities according to established rituals and traditional beliefs based on a deep knowledge of water and underground evacuation channels in case of flash floods. Unfortunately, this knowledge was lost, and the new settlements built without respecting the ancestral rituals which were based on a practical knowledge of local hydrology were terribly affected by floods in 2010 (Sharma, 2012).

Regarding earth constructions in the Argentine Northwest: "The transfer of the knowledge of how to choose the earth, prepare it, let it "sleep" one, three, five days, spread the straw, prepare the area, "cut" the adobe, let it dry and stack it; is part of the daily work of family life, passed along with other tasks, such as preparing the land to sow the seeds, spinning the wool to weave the blankets for winter or shelling the corn to prepare and season the humita. It is these customs and daily tasks, particular and typical of the community, that over time generated the identity of the region, and the character of a recognized intangible heritage." This knowledge, unfortunately, is being lost because of the massive insertion of new materials, or the influence of "modernity" or the new cultural patterns brought by outsiders settled in the region (Del Huerto, Josefina, 2012).

Cristian Heinsen, regarding the work of the Altiplano Foundation in Arica and Parinacota, Chile, indicates that "when you arrive in a community asking who knows how to work with earth, most likely no one will respond. The wise adobero of the community, tired of the disregard for his inherited knowledge, will remain silent expectant and distrustful, as it corresponds when someone arrives very interested in locating a treasure." For Heinsen, "the revaluation of earth as a constructive element coincides with the vindication of indigenous or ancestral cultures and with the decolonization of knowledge" (Heinsen, Cristian, personal communication, July, 2019).
According to Graciela Viñuales, earthen architecture construction "is not taught in technical schools or universities, there are not enough norms and regulations written and it hardly appears in the books of structures or technology" (Viñuales, Graciela, personal communication, 2019).

2.4.5 Lack of Maintenance: The lack of preventative conservation is a symptom of the loss of the culture of maintenance in general, but it specially affects earthen construction because of its fragility and susceptibility to water and earthquakes.

In several examples mentioned before, we saw that many of the collapses caused by seismic movements occurred in homes or monuments that had not received proper maintenance. The accumulating effect of earthquakes requires constant maintenance, otherwise, it eventually results in partial or total collapse. As I mentioned earlier, earthen constructions can offer a habitat for insects and invasive vegetation but only when they are riddled with cracks and holes. A well-preserved adobe or tapial wall can be as much or more sanitary than a concrete or brick wall.
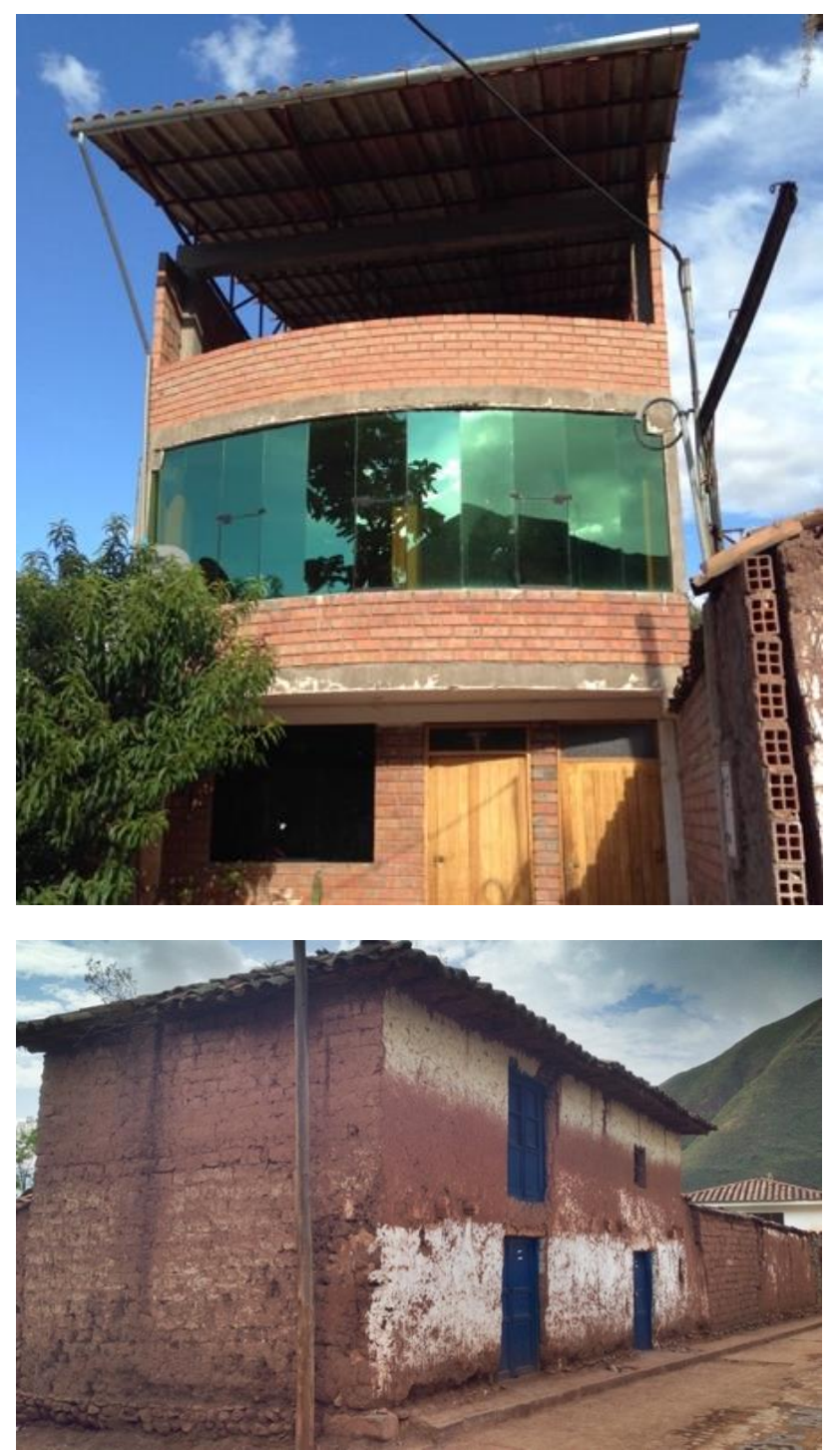

Figure 4. Houses in Cusco, Peru. 


\subsubsection{Inappropriate Interventions}

According to Graciela Viñuales, most of the damage in earthen structures is caused by interventions carried out with incompatible criteria and materials, applied with the goal of "reinforcing" or "improving" the material or its design: "The most common is when an earth structure deteriorates, the architects accustomed to iron, concrete, lime and cement, decide that the solution is to incorporate this type of materials to give it solidity. "Thus abandoning the basic concepts of continuity, homogeneity, adhesion - in terms of construction - and of unity, texture and color, in the visual and morphological sense" (Viñuales, 2009).

The most common intervention is the replacement of mud plaster with a cement one, especially in the lower parts of the walls where the wall is most exposed to use. This obviously creates an impermeable layer that traps the moisture rising by capillarity, causes the accelerated deterioration of the mud wall and eventually, when the cement coat falls due to lack of adhesion, it drags with it-parts of the original wall.

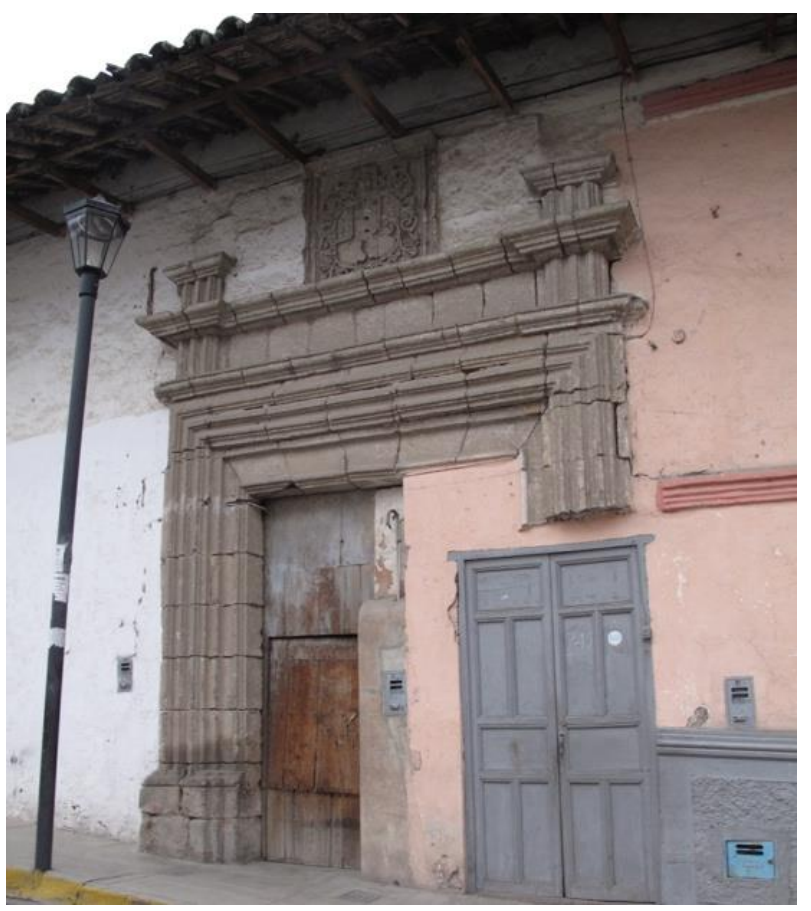

Figure 5. Inappropriate interventions.

The introduction of openings and additions of incompatible materials that cause detachment and separation, or "hammering" during earthquakes, contribute to the loss of the structural unit of the construction.

Finally, deterioration due to lack of maintenance or failures caused by inappropriate interventions contribute to a poor perception of the material. This process results in the replacement of a viable, economical and locally accessible construction tradition, with other technologies and materials that not only require a greater investment, but because of their production and transportation leave a greater carbon footprint in the environment.

In contrast, seismic reinforcement, installation of adequate drainage infrastructure, use of appropriate restoration designs and techniques and continuous maintenance, are the key to the sustainability of earthen constructions, especially in seismic or flood-threatened areas.

\section{LEGISLATION}

Legislation may be a threat or an opportunity for the preservation of earth building systems, depending on the intention and scope of the regulations. However, although there have been significant advances in recent decades, earthen architecture is neglected in many local and regional development plans. Here are some cases of earth construction legislation in Latin America, including threats and opportunities:

In Argentina, 100 of the 1400 national monuments are made of adobe and many are in the Andean provinces, between Jujuy and Mendoza. Although adobe is still used as a construction material, it is illegal in several regions, especially in seismic areas such as San Juan, destroyed by the 1944 earthquake. However, as of 2010, different groups of environmentalists, architects and civil engineers have been developing research and practices on different alternative construction techniques with low environmental impact, using raw earth, straw, cane framework and waste materials. Finally, this work resulted in the establishment of public ordinances that enable, regulate and promote these types of constructions. The city of Santa Rosa was the first to establish this regulation in 2015, followed by Mar del Plata, Bariloche and Chubut among others (Gioberchio, Graciela, 2016).

In Chile, Cristian Heinsen of the Altiplano Foundation comments that "when in 2003 we resolved to respond to the request for help from small Andean communities that wanted to preserve their centuries-old temples, adobes, stones and straw, located in ravines and mountains of Arica and Parinacota, as exquisite manifestations of the indigenous and mestizo spirituality of America, the message from the Academy and the Government was to conserve the shape of the buildings, but replace their soul, the earth material, with another 'noble' or modern material, that complied with the strict norms of construction safety, revealed by engineering science" (Heinsen, Cristian, personal communication, July, 2019). Years later, and in response to the massive damage caused by the 2010 earthquake, the Chilean Government through the Ministry of Housing and Urban Development developed, in collaboration with Peruvian experts, the Technical Standard Minvu NTM 002, which was established in 2013 to regulate the alteration, restoration, rehabilitation, remodeling, repair or structural consolidation of earth constructions in Chile. However, new construction with this material is not yet regulated in the country.

In Barichara, Colombia, almost all new constructions are made of tapial, all licensed by the Mayor's Office, although the current construction code does not accept it as a construction system. The reasons for this urban phenomenon, according to Santiago Rivero Bolaños, are that Barichara's heritage value is recognized nationally and internationally, it has a workforce skilled in this construction technique and the client profile that requests this architecture is of very high cultural and academic level (Rivero, 2007).

In Costa Rica, following the earthquake of 1910 that devastated the city of Cartago, then the capital of the country, for a second time, the government launched a Presidential Decree of immediate compliance, which prohibits the construction of adobe in the city: "Art. 14: The use of adobes, calicanto or stone will not be allowed in any kind of constructions, within the city. This prohibition is extended to the other districts of the canton." In addition, by not including regulations on how to restore or seismically reinforce this type of construction, many were demolished (Hernández, 2014). 
In Peru, a country that has pioneered the development of earthquake-resistant design standards, the Technical Standard E080 of the Ministry of Housing, Construction and Sanitation, prepared in 1985 and revised in 2006 and 2017, regulates reinforced adobe constructions. The law cites as its objectives: Design buildings of social interest and low cost that can resist seismic actions, preventing the possibility of their collapse (2006); Promote the benefits of reinforced earth construction, their accessibility, low cost, ecological and environmental virtues, low energy consumption, thermal and acoustic insulation, its traditional forms and rustic textures (2017). This Peruvian standard has served as the basis for other technical regulations in the world such as in India and Nepal (Blondet, 2005).

\section{PRESERVATION OF EARTHEN ARCHITECTURE}

Natural processes dictate that perishable construction materials such as earth, wood and paint, be consumed by the sun, rain, bacteria, insects or are violently decimated by earthquakes, hurricanes or torrential rains. In other words, conservation goes against the dynamics of nature itself (Rodríguez, 2003). To these natural threats we must add those anthropogenic such as wars, development pressure, architectural fashions and, unfortunately, ignorance.

Construction methods now considered traditional, such as earthen architecture, were the result of decades or centuries of trial and error processes through which the combinations of materials and constructive details that proved to be the best and most appropriate to the local reality survived. Architecture converted into heritage through socio-cultural processes remains architecture and therefore the construction logic mentioned above remains an important factor in its preservation.

The processes of architectural creation continue during the useful life of the structure, as well as changes in the needs and tastes of users, the availability of new materials or the disappearance of others, some historical challenges worsen, or new threats need to be addressed. Built heritage is a living and changing subject whose preservation is not governed by the same rules of movable or museum heritage.

However, a basic principle of conservation in any constructive typology is to use materials and technology compatible with those that it was built of, and this principle is even more important in the case of earthen architecture. Incompatible interventions such as concrete or brick additions in earth constructions, often produce negative results such as in the city of Bam, Iran, razed by the 2003 earthquake, or in the Pisco Cathedral, destroyed by the 2007 earthquake, or in the Gingerbread Houses of Haiti, affected by the 2010 earthquake.

Furthermore, constant maintenance is key in long-term conservation, especially in earthen constructions. Some important examples of participatory maintenance, mentioned before are the Great Mosque of Djenné in Mali and the Royal Court of Tiébelé in Burkina Faso, which are comparable to the repaje (rethatching) ceremony of the Marcapata church in Cusco, declared Cultural Heritage of the Nation in 2015. These traditions, which constitute an intangible heritage in itself, not only help to preserve the material cultural heritage, but also contribute to the generation of economic resources through cultural tourism.

However, the spirit of this minga or shared work dedicated to the conservation of those monuments that are of great importance to the community, should be applied to the maintenance of simple houses, deposits or fences built of earth.
It is this vernacular, self-constructed, common and utilitarian architecture that is most threatened and in danger of disappearing. Its current "preservation by neglect" cannot be sustained for much longer.

An interesting example of community maintenance occurs in Lampa, Puno, one of the most beautiful and best-preserved historical cities in Peru, known as the "pink city." Lampa's stone and adobe constructions are regularly painted by neighbors or the Municipality using a type of clay known as chocorosí, which is obtained from nearby hills. However, this habit of repainting with natural pigments is gradually being replaced by the use of plastic paints.

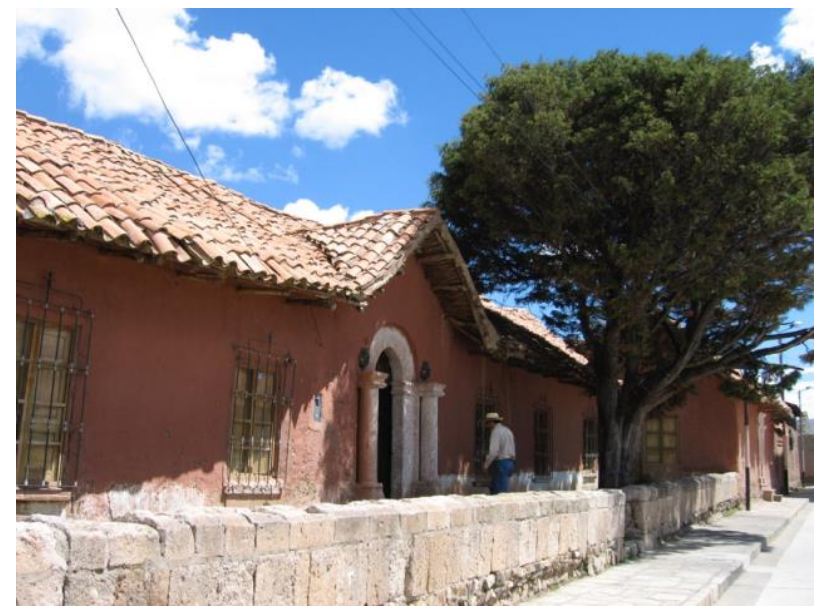

Figure 6. Lampa, Puno.

\section{CONCLUSIONS}

What can be done to preserve and promote earthen construction in areas where this type of construction is most appropriate for geographical, climatic or economic reasons?

Promote adobe structural and seismic reinforcement techniques such as compressed earth blocks (CEBs), the use of geotextiles or nylon ropes, galvanized steel trusses or tensors, or stabilization with lime or polymer fibers?; or promote new and more efficient earth construction techniques such as prefabricated quincha?; or build houses of adobe reinforced with seaweed?; or build structures of earth contained in bags such as those proposed by the Iranian architect, Nader Khalili?

In any case, cost, availability and durability of the proposed reinforcement materials should be prioritized in their selection.

Many earthen architecture projects, consisting of either new construction or seismic reinforcement, are generally led by international support agencies, governments or academic researchers (PUCP, JICA, etc.), which in many cases failed to create long-standing and entrenched local capacity. Undoubtedly, more research is needed but also more participatory processes, long-term national policies and effective knowledge and technology transfer programs.

Since earthen constructions require constant renovation and maintenance, and its preservation is not simply about conserving the physical or material object, but mainly about the preservation of its construction and maintenance techniques, the local socio-cultural knowledge system of this type of construction becomes an intangible heritage asset that requires valorization, documentation and promotion. 


\section{ACKNOWLEDGMENTS}

To Cristian Heinsen, Eduardo Gamboa, Graciela Viñuales, Isidora Larraín, Lisy Kuon, Oscar Centurión, Ramón Gutiérrez, Robert Aréstegui, Silvia de los Ríos, Sofía Rodríguez Larraín and Víctor Marín for their generous contributions to this paper.

\section{REFERENCES}

Aranda, Yolanda, Suárez D., Edgardo, 2014: Análisis experimental para determinar la productividad térmica en la tierra vertida. $14^{\circ}$ Seminario Iberoamericano de Arquitectura y Construcción con Tierra (SIACOT). San Salvador, El Salvador: Imprimatic S.A. pp. 76-79.

Beltrán, Lina C., 2007: La tradición cultural de los sistemas constructivos en tierra en Iberoamérica. Arquitectura en tierra, Apuntes vol. 20, núm. 2. pp. 179-181. Bogotá, Colombia: Facultad de Arquitectura y Diseño, Pontificia U. Javeriana.

Blondet, Marcial, Vargas, Julio, Tarque, Nicola, 2005: Reflexiones sobre la normatividad para la construcción sismo resistente de edificaciones de adobe. Primer Congreso-Taller Internacional para la normalización de la Arquitectura de Tierra. Mexico, Tampico: Universidad Autónoma de Tamaulipas.

Canziani, José, 2012: Arquitectura Monumental de Adobe en el Perú Prehispánico: su temprana evolución histórica y los retos de conservación. Terra 2012. Lima, Perú.

Cherradi Akbil, Faissal, 2012: Arquitectura de tierra en el sur de Marruecos. Terra 2012. Lima, Perú.

Del Huerto, Josefina, Sosa, Mirta, 2012: El Saber Construir con Tierra- Patrimonio Intangible del Noroeste Argentino. Terra 2012. Lima, Perú.

Garzón, Lucia, 2012: Aporte de la quincha pre-fabricada en Colombia: Análisis de la tecnología en aspectos ambientales y energéticos. Terra 2012. Lima, Perú.

Gasparini, Graziano, 2009: Escuchar al Monumento. Caracas, Republica Bolivariana de Venezuela: Editorial Arte.

Gayoso, Magaly, Pacheco, Orlando, 2014: Vivienda alpaquera altoandina. Caso de estudio tipológico en Puno, Perú. $14^{\circ}$ Seminario Iberoamericano de Arquitectura y Construcción con Tierra (SIACOT). San Salvador, El Salvador: Imprimatic S.A. pp. 88-94.

Gioberchio, Graciela, 2016: Aprueban la construcción en adobe en diferentes ciudades del país. Clarín.

Giuliani, F. et al., 2008: El Terremoto de Pisco-Perú, 15 de Agosto de 2007. Lima, Perú: CERESIS/UNESCO.

González, Georgina, 2018: Con las manos en el barro para llegar a la casa propia. LMNeuquen.com.

Guillaud, Hubert, 2003: An approach to the evolution of earthen building cultures in Orient and Mediterranean regions: What future for such an exceptional legacy ?. Al-Räfidān: Journal of Western Asiatic Studies. Tokio: Kokushikan Daigaku. Iraku Kodai Bunka Kenkyūjo.
Hassel, B. Ivón, Kitamori, Akihisa, Kiho, Jung, Komatsu, Kohei, 2013: Prefabricated mud wall units based on a traditional Japanese building system: Lateral in-plane performance in terms of connection, and crack development using digital speckle photography. International Journal for Research and Development.

Hernández Salazar, Ileana, 2014: Restauración de Arquitectura de Tierra en Zonas Sísmicas. Valencia, España: Universidad Politécnica de Valencia.

Hurtado, Pedro, 2012: Aprendiendo del pasado: los muros de adobe y bóvedas de entramados de tierra de la iglesia la Compañía de Pisco- Perú frente a los terremotos. Terra 2012. Lima, Perú.

Mendoza, Olga, 2012: Arquitectura de tierra tradicional en Japón frente a los desastres naturales. Terra 2012. Lima, Perú.

Pastor, Diana (2018). El adobe no es pobreza, es resiliencia. Entremundos.

Quiun, Daniel, Cadillo, Antonio, 2012: Inspección de estructuras de adobe construidas en programas de vivienda desarrollados hace más de veinticinco años en el norte de Perú. Terra 2012. Lima, Perú.

Rivero, Santiago, 2007: El uso masivo de la tierra como material de construcción en Colombia. Arquitectura en tierra, Apuntes vol. 20, núm. 2. pp. 354-363. Bogotá, Colombia: Facultad de Arquitectura y Diseño, Pontificia U. Javeriana.

Rodríguez Romo, Fernando, 2003: Conservación de Tipologías Constructivas Tradicionales. Valencia, Republica Bolivariana de Venezuela: INDUVAL Instituto de Desarrollo Urbano del Centro de Valencia.

Sánchez, Mauricio, 2012: Criterios de intervención y obras de emergencia de los monumentos nacionales de chile dañados por el terremoto del 2010. Terra 2012. Lima, Perú.

Sharma, Tara, 2012: Guardians of the Earth: Cultural Dimensions of Earthen Architecture in Ladakh. Terra 2012. Lima, Perú.

Taucer, Fabio (Ed.). 2008: 2007 August 15 Magnitude 7.9 Earthquake near the Coast of Central Perú. Earthquake Field Investigation Team (EEFIT) Field Mission, 5-12 SEPTEMBER 2007 / Final Report. Luxembourg: Office for Official Publications of the European Communities.

Vargas, Yalmar, 2012: Actualización del patrimonio arquitectónico de tierra de las comunidades indígenas en Colombia. Terra 2012. Lima, Perú.

Viñuales, Graciela, 2009: Restauración de Arquitectura de Tierra. Buenos Aires, Argentina: CEDODAL. 